Silicon has opposite effects on the accumulation of inorganic and methylated arsenic species in rice

Author(s): Wen-Ju Liu, Steve P. McGrath and Fang-Jie Zhao

Source: Plant and Soil, Vol. 376, No. 1/2 (March 2014), pp. 423-431

Published by: Springer

Stable URL: https://www.jstor.org/stable/42953122

Accessed: 01-10-2020 19:51 UTC

JSTOR is a not-for-profit service that helps scholars, researchers, and students discover, use, and build upon a wide range of content in a trusted digital archive. We use information technology and tools to increase productivity and facilitate new forms of scholarship. For more information about JSTOR, please contact support@jstor.org.

Your use of the JSTOR archive indicates your acceptance of the Terms \& Conditions of Use, available at https://about.jstor.org/terms

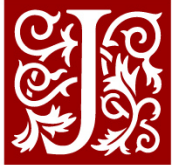




\title{
Silicon has opposite effects on the accumulation of inorganic and methylated arsenic species in rice
}

\author{
Wen-Ju Liu • Steve P. McGrath • Fang-Jie Zhao
}

Received: 12 October 2013 / Accepted: 21 November 2013/Published online: 14 December 2013

() Springer Science+Business Media Dordrecht 2013

\begin{abstract}
Background and aims Rice (Oryza sativa) is a main source of human exposure to inorganic arsenic and mitigation measures are needed to decrease As accumulation in this staple crop. It has been shown that silicon decreases the accumulation of arsenite but, unexpectedly, increases the accumulation of dimethylarsinic acid (DMA) in rice grain. The aim of this study was to investigate why $\mathrm{Si}$ increases DMA accumulation.

Methods Pot and incubation experiments were conducted to investigate how the addition of sparingly soluble silicate gel affected As speciation in the soil solution and the accumulation of different As species in rice tissues. Results Silicon addition significantly decreased the concentration of inorganic As (mainly arsenite) but increased the concentration of DMA in both the vegetative and reproductive tissues of rice. Silicon increased the
\end{abstract}

Responsible Editor: Henk Schat.

\footnotetext{
W.-J. Liu - S. P. McGrath

Department of Sustainable Soil and Grassland Systems, Rothamsted Research, Harpenden, Hertfordshire AL5 2JQ, UK

W.-J. Liu

College of Resources and Environmental Science, Hebei Agricultural University, Baoding, Hebei Province 071001, China

F.-J. Zhao (ه)

Laboratory of Plant Nutrition and Fertilization in Low-Middle Reaches of the Yangtze River, Ministry of Agriculture, College of Resources and Environmental Sciences, Nanjing Agricultural University, Nanjing 210095, China

e-mail: fangjie.zhao@njau.edu.cn
}

concentration of DMA in the soil solution, whereas autoclaving soil decreased DMA concentration. Less DMA was adsorbed by the soil than arsenate and $\mathrm{Si}$ addition significantly inhibited DMA adsorption.

Conclusions Silicon increased DMA accumulation and decreased arsenite accumulation in rice through different mechanisms. Silicic acid released from the silicate gel increased the availability of DMA for rice uptake by inhibiting DMA adsorption on the soil solid phase or by displacing adsorbed DMA. Although silicic acid also increased the concentration of inorganic As in the soil solution, this effect was much smaller than the inhibitory effect of $\mathrm{Si}$ on arsenite uptake by rice roots.

Keywords Arsenic - Arsenic speciation - Arsenite · Methylated As $\cdot$ Rice $\cdot$ Silicon

\section{Introduction}

Contamination of the food chain with arsenic (As) is a serious issue in some regions of the world, especially in some rice producing areas (European Food Safety Authority 2009; Meharg and Zhao 2012). Rice is inherently efficient at accumulating As from paddy soils ( $\mathrm{Su}$ et al. 2010; Williams et al. 2007b), where As becomes more bioavailable due to the mobilization of arsenite under the anaerobic conditions (Stroud et al. 2011; Xu et al. 2008). Irrigation of As-contaminated groundwater, impacts of mining and smelting, and past uses of Ascontaining agrochemicals may further elevate As concentration in the soil and its transfer to food crops (Panaullah et al. 2009; Williams et al. 2007a; Zhu 
et al. 2008). Consumption of rice constitutes a major route of human exposure to inorganic As, a class-one carcinogen (Meharg and Zhao 2012).

In addition to inorganic As (arsenite and arsenate), rice grain also contains varying amounts of methylated As species, especially dimethylarsinic acid (DMA) (Lombi et al. 2009; Meharg et al. 2009; Zavala et al. 2008). Depending on the growth region, soil conditions and rice cultivars, DMA can account for between $10 \%$ and $90 \%$ of the total As in rice grain (Zhao et al. 2013b). Other species of methylated As such as monomethylarsonic acid (MMA) and tetramethylarsonium ion have occasionally been found in some grain samples at low concentrations (Hansen et al. 2011; Meharg et al. 2009). Whilst methylated As species containing pentavalent As are less toxic to animals and humans (Zhao et al. 2013b), DMA has a tendency to accumulate preferentially in the reproductive organs of rice (Carey et al. 2010; Lomax et al. 2012; Zheng et al. 2011) and is suspected to be a cause of the straight-head disorder (spikelet sterility) (Meharg and Zhao 2012). Therefore, understanding the factors controlling As speciation in rice is important not only for food safety but also for preventing this Asrelated physiological disorder in rice.

A number of mitigation measures have been suggested to reduce As accumulation in rice, such as selection and breeding of cultivars low in As accumulation, management of paddy water to control As bioavailability, and use of silicon (Si) fertilizers to decrease As uptake (Zhao et al. 2010). The use of Si fertilizers is based on the discovery that arsenite, the predominant form of As in flooded paddy soil, is taken up via the $\mathrm{Si}$ transport pathway in rice roots (Ma et al. 2008). Two silicic acid transporters, Lsil and Lsi2, are both able to transport arsenite. The efflux transporter Lsi2, which is responsible for the efflux of silicic acid and arsenite towards the stele for xylem loading, plays a particularly important role in the accumulation of As in the shoot tissues of rice (Ma et al. 2008). Due to an antagonistic effect, Si additions were found to decrease the accumulation of As in rice grain and straw markedly in pot experiments, (Fleck et al. 2013; Li et al. 2009b; Seyfferth and Fendorf 2012). Variation in the availability of Si among soils also appears to correlate inversely with As accumulation in rice (Bogdan and Schenk 2008; Khan et al. 2010). Surprisingly, Si additions resulted in a significant increase in the concentration of DMA in rice grain and husk by unknown mechanisms ( $\mathrm{Li}$ et al. 2009b).
Emerging evidence suggests that methylated As species in rice are derived from the soil, as rice plants lack the ability to methylate inorganic As (Arao et al. 2011; Jia et al. 2012; Lomax et al. 2012; Zhao et al. 2013b). Therefore, we hypothesize that Si supply increases the availability of methylated As species in the soil, resulting in enhanced accumulation of DMA in rice plants. This hypothesis was tested in a series of pot and incubation experiments designed to investigate the effect of $\mathrm{Si}$ on the As speciation in soil solution and rice plants.

\section{Materials and methods}

Soil

A silty clay loam (Aquic Paleudalf, USDA classification) was collected from the plough layer $(0-20 \mathrm{~cm})$ of an arable field on the Rothamsted farm, Southeast England. The soil contained $1.42 \%$ organic C, $0.13 \%$ total $\mathrm{N}$ and $11.6 \mathrm{mg} \mathrm{As} \mathrm{kg}^{-1}$ with a $\mathrm{pH}$ value of 5.2. The soil was air dried, sieved to $<8 \mathrm{~mm}$ and homogenized.

\section{Pot experiments}

Two pot experiments were conducted with two different rice cultivars (cv. Oochikara and Italica Carolina, both of the Japonica type, the latter an early flowering cultivar). Two treatments were included in each experiment: control (-Si) and $+\mathrm{Si}\left(20 \mathrm{~g}\right.$ of $\mathrm{SiO}_{2}$ gel $/ \mathrm{kg}$ soil) in the form of silica gel (Fuji Silysia Chemical Ltd.). This provides a sparingly soluble source of $\mathrm{Si}$ for rice plants and does not significantly affect soil $\mathrm{pH}$ ( $\mathrm{Li}$ et al. 2009b). Silicic acid is the form present in the soil solution and taken up by plants. For the experiment with $\mathrm{cv}$. Oochikara, each treatment was replicated in 16 pots to allow sampling at panicle emergence (4 days before flowering) and 1, 2 and 3 weeks after flowering; 4 replicates were sampled each time. For the experiment with cv. Italica Carolina, each treatment was replicated four fold and plants were sampled at grain maturity only. Each pot contained $1 \mathrm{~kg}$ air-dried soil. Silica gel and basal fertilizers $\left(120 \mathrm{mg} \mathrm{N} \mathrm{kg}{ }^{-1}\right.$ soil as $\mathrm{NH}_{4} \mathrm{NO}_{3}$, $25 \mathrm{mg} \mathrm{S} \mathrm{kg}^{-1}$ soil as $\mathrm{MgSO}_{4}, 30 \mathrm{mg} \mathrm{\textrm {Pg } ^ { - 1 }}$ soil and $75.5 \mathrm{mg} \mathrm{K} \mathrm{kg}{ }^{-1}$ soil as $\mathrm{K}_{2} \mathrm{HPO}_{4}$ ) were added to the soil and mixed thoroughly. A Rhizon soil solution sampling device (Rhizon MOM $10 \mathrm{~cm}$ length, $2.5 \mathrm{~mm}$ OD, Rhizosphere Research Products, Wageningen, The 
Netherlands) was buried in the soil for collecting soil solution. A standing head of water $(\sim 3 \mathrm{~cm})$ was maintained in the pots for 1 week before two rice seedlings were transplanted into each pot. Rice was grown under flooded conditions using deionized water throughout the entire rice growth period. Further doses of fertilizers ( $60 \mathrm{mg}$ of $\mathrm{N}, 15 \mathrm{mg}$ of $\mathrm{P}$, and $38 \mathrm{mg}$ of $\mathrm{K}$ ) were added into each pot at tillering and stem extension stages. The experiments for the cv. Oochikara and Italica Carolina were conducted during December 2008 - May 2009 and August - November 2010, respectively, inside a glasshouse with natural sunlight supplemented with sodium vapour lamps to maintain a light intensity of $>350 \mu \mathrm{mol} \mathrm{m}^{-2} \mathrm{~s}^{-1}$. The light period was $16 \mathrm{~h}$ per day and day/night temperatures were maintained at $28 / 25^{\circ} \mathrm{C}$.

At each sampling, main tillers were cut and separated into 6 or 7 components: ears (which were further separated into husk and brown rice grain at 2 and 3 weeks after flowering), leaves 1 to 4 (leaf 1 being the flag leaf at the top) and stems, respectively. All plant tissues were rinsed with deionized water, blotted dry and ground to powder in liquid nitrogen.

Soil solutions were collected at different time points during plant growth and preserved with $10 \mathrm{mM}$ EDTA (Xu et al. 2008) in the experiment with cv. Oochikara or with $\mathrm{HCl}$ (acidified to $\mathrm{pH}<2.0$ ) in the experiment with cv. Italica Carolina (Zhao et al. 2013a).

\section{Soil incubation experiments}

An incubation experiment was set up to investigate the effects of autoclaving soil and $\mathrm{Si}$ addition on As species dynamics in soil solution. Air-dried soil $(300 \mathrm{~g},<4 \mathrm{~mm})$ was placed in a plastic container. Treatments included factorial combinations of autoclaving and nonautoclaving, with or without an addition of $\mathrm{Si}(20 \mathrm{~g}$ $\mathrm{SiO}_{2}$ gel kg ${ }^{-1}$ soil). Soil was incubated under flooded conditions for 64 days. Soil solution was collected on day 20,50 and 64 and acidified with $\mathrm{HCl}$ to $\mathrm{pH}<2.0$.

In a further incubation experiment, the effect of $\mathrm{Si}$ (as silicic acid) on the partitioning of arsenate $(\mathrm{As}(\mathrm{V}))$ or DMA between the soil solid and solution phases was investigated. An addition of As(III) was not included as our previous study showed that As(III) was rapidly oxidized to $\mathrm{As}(\mathrm{V})$ after contact with soil under aerobic conditions (Xu et al. 2008): Treatments included factorial combinations of control (no addition of $\mathrm{As}),+\mathrm{As}(\mathrm{V})$ or+DMA, with or without an addition of Si. Each treatment had 3 replicates. The amounts of As and $\mathrm{Si}$ added were equivalent to $1 \mathrm{mg} \mathrm{As} \mathrm{kg}{ }^{-1}$ and $25 \mathrm{mg} \mathrm{Si}$ $\mathrm{kg}^{-1}$ soil, respectively. Because this was a short-term experiment, soluble silicic acid was used instead of the sparingly soluble $\mathrm{SiO}_{2}$ gel. Briefly, $4 \mathrm{~g}$ air-dried soil $(<4 \mathrm{~mm}$ ) was weighed into a $50 \mathrm{~mL}$ centrifuge tube, to which $2 \mathrm{~mL}$ of deionized water, $\mathrm{As}(\mathrm{V})$ or DMA solution was added and mixed. Two $\mathrm{h}$ later, $38 \mathrm{~mL}$ of $10 \mathrm{mM}$ $\mathrm{CaCl}_{2}$ or a mixed solution containing $0.94 \mathrm{mM}$ silicic acid and $10 \mathrm{mM} \mathrm{CaCl}_{2}$ (both with $\mathrm{pH}$ adjusted to 6.4 ) were added. The tubes were shaken for $2 \mathrm{~h}$ in a shaker $(15 \mathrm{rpm})$ at $20^{\circ} \mathrm{C}$, and then centrifuged at $3000 \mathrm{rpm}$ for $15 \mathrm{~min}$. The supernatants were filtered through a $0.45 \mu \mathrm{m}$ membrane filter and acidified with $\mathrm{HCl}$ to $\mathrm{pH}<2.0$ before As species analysis.

\section{Analysis of As species}

In the pot experiment with cv. Oochikara, plant tissues ground in liquid nitrogen were extracted with $10 \mathrm{ml}$ phosphate buffer solution $\left(2 \mathrm{mM} \mathrm{NaH} \mathrm{PO}_{4}\right.$ and $0.2 \mathrm{mM} \mathrm{Na}_{2}$-EDTA, pH 6.2) (Xu et al. 2008) for $1 \mathrm{~h}$ under sonication in a cold room $\left(4^{\circ} \mathrm{C}\right)$. The extract was filtered through No.42 Whatman filter paper, followed by filtration through $0.2 \mu \mathrm{m}$ and then analyzed for As speciation using HPLC-ICP-MS. In the experiment with cv. Italica Carolina, mature grain was ground into fine powder. Aliquots of grain samples $(0.5 \mathrm{~g})$ were extracted with $2 \mathrm{~mL} 2 \mathrm{M}$ trifluoroacetic acid (TFA) according to Williams et al. (2005). Because arsenate may be partially reduced to arsenite during TFA extraction (Williams et al. 2005), the sum of arsenite and arsenate was presented as inorganic As. A certified reference material (NIST1568a rice flour) and blank were included for As speciation and the results obtained were in good agreement with those reported previously ( $\mathrm{Li}$ et al. 2009b).

Statistical analysis

Significance of treatment effects was assessed by analysis of variance using Excel 2007 for Windows.

\section{Results}

Arsenic species in soil solution

In the first pot experiment with cv. Oochikara, As(III) and $\operatorname{As}(\mathrm{V})$ were found in the soil solutions with $\mathrm{As}(\mathrm{III})$ 
accounting for $>87 \%$ of the total As and the remainder being $\mathrm{As}(\mathrm{V})$. No methylated As species were detected (data not shown). The dynamics of As species were similar to those reported previously using the same soil (Li et al. 2009b). However, the lack of detection of methylated As species was likely to be an artefact due to the use of EDTA to preserve the soil solution samples, as our recent study showed that this sample preservation method, while satisfactory for preserving inorganic As species, resulted in an underestimation of methylated As species such as DMA (Zhao et al. 2013a). Therefore, in the second pot experiment with cv. Italica Carolina, soil solution samples were preserved with $\mathrm{HCl}$ acidification which was found to preserve both inorganic As and DMA species (Zhao et al. 2013a).

$\operatorname{As}(\mathrm{III}), \operatorname{As}(\mathrm{V})$ and DMA were detected in the soil solution sampled at the flowering stage in the experiment with cv. Italica Carolina. In the treatment with $\mathrm{SiO}_{2}$ gel ( $\mathrm{Si}$ concentration in the soil solution was $1.0 \mathrm{mM}$ ), the DMA concentration in soil solution was approximately double of that in the control treatment $(P<0.001)$, whereas the concentrations of As(III) and $\operatorname{As}(V)$ did not differ significantly between the two treatments (Fig. 1). As a result, DMA accounted for a larger percentage $(21.7 \%)$ of the total solution $\mathrm{As}$ in the $+\mathrm{Si}$ treatment than in the - Si treatment $(11.6 \%)$.

The effect of Si on the dynamics of As species in soil solution was further investigated in an incubation study without growing rice plants, with the soil being either autoclaved or not. As(III), As(V), DMA and occasionally, MMA, were detected in the soil solutions (Fig. 2), although MMA concentrations were very low (MMA data not presented in Fig. 2). The As(III) concentration

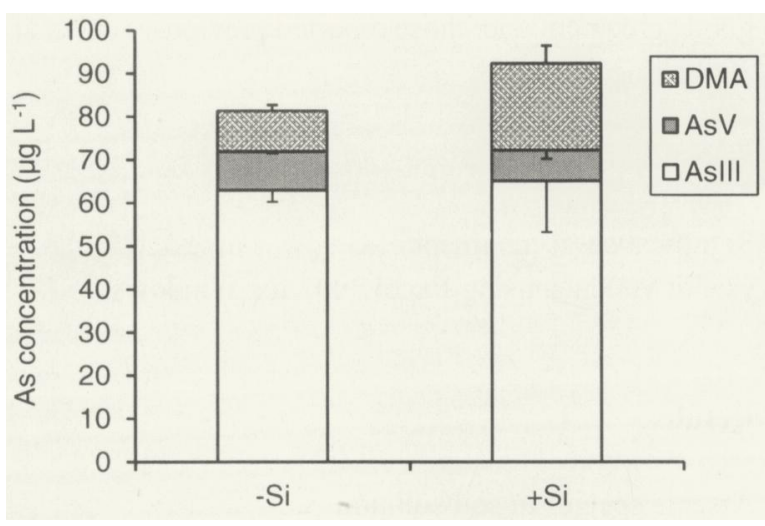

Fig. 1 Effect of Si addition on As speciation in the soil solution collected at the flowering stage of rice (cv. Italica carolina) (Data are means $\pm \mathrm{SE}, n=4$ ) showed an increasing trend with incubation time, whilst $\operatorname{As}(\mathrm{V})$ and DMA concentrations increased initially and then decreased with time. The ratio of $\mathrm{As}(\mathrm{III})$ to $\mathrm{As}(\mathrm{V})$ increased with incubation time, consistent with the development of reducing conditions in the flooded soil. The decrease in DMA concentration after 50 days may be due to demethylation or volatilization of methylarsine (Zhao et al. 2013a). Autoclaving did not completely sterilize the soil as shown by the presence of bacterial colonies on agar plates inoculated with soil solution samples. However, autoclaving decreased the concentrations of As(III) and DMA in soil solution significantly $(P<0.01)$ compared with the unautoclaved control, but had little effect on $\mathrm{As}(\mathrm{V})$ concentration (Fig. 2). The concentration of DMA ranged from 3.0 to $9.8 \mu \mathrm{g} \mathrm{L}^{-1}$ in the soil solution from the autoclaved treatment $(13-15 \%$ of the total solution As), compared with $6.3-26 \mu \mathrm{g} \mathrm{L}^{-1}$ from the nonautoclaved soil (13 - $21 \%$ of the total solution As). The addition of Si significantly $(P<0.05)$ increased the concentrations of $\mathrm{As}(\mathrm{III})$ on day 64 , of $\mathrm{As}(\mathrm{V})$ on day 50 $(P<0.01)$ and day $64(P<0.05)$, of DMA on days 50 and 64 for autoclaved soil (Fig. 2). The increase in DMA concentration varied from $21 \%$ to 8.5 fold.

Effect of Si on the partitioning of As species between the soil solid and solution phases

After a short contact period ( $2 \mathrm{~h}$ ), most (98-99\%) of the As $(\mathrm{V})$ added to the soil was partitioned into the soil solid phase most likely due to adsorption (Fig. 3). The addition of $\mathrm{Si}$ in the form of silicic acid had a small but significant $(P<0.01)$ effect on the partitioning of $\mathrm{As}(\mathrm{V})$ between the solid and solution phases. In comparison, smaller percentages ( $78-82 \%$ ) of the added DMA were retained in the solid phase, resulting in substantially higher concentrations of DMA in the solution phase than in the amendment with As(V) (Fig. 3). Furthermore, Si significantly $(P<0.01)$ increased the concentration of DMA in the soil solution while decreasing its partitioning to the soil solid phase. This effect was larger than that on the partitioning of $\mathrm{As}(\mathrm{V})$.

\section{Effect of Si on As species in rice tissues}

In the first pot experiment with cv. Oochikara, panicles emerged approximately 1 week earlier in the $+\mathrm{Si}$ treatment than in the $-\mathrm{Si}$ treatment. To allow comparisons between the two treatments, plant samples were taken at 

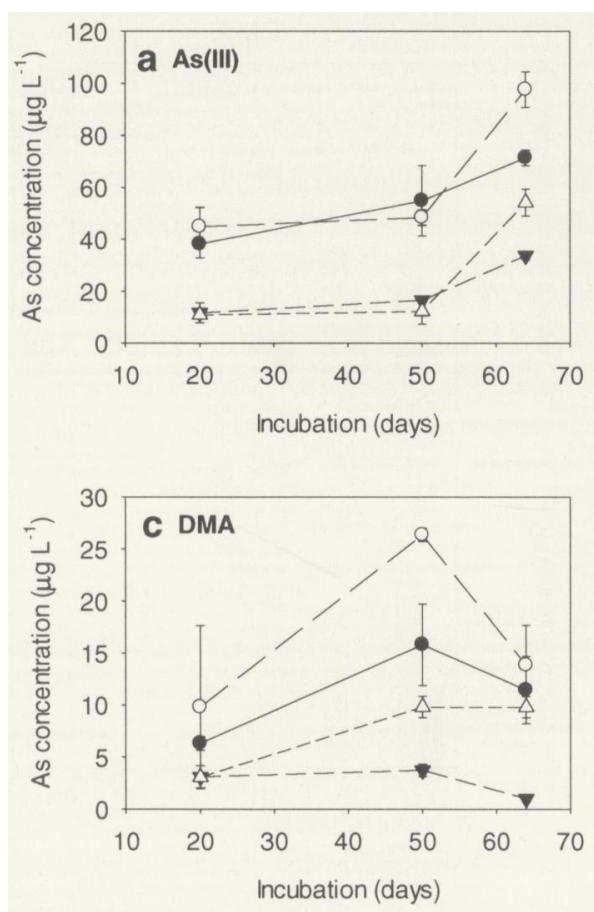
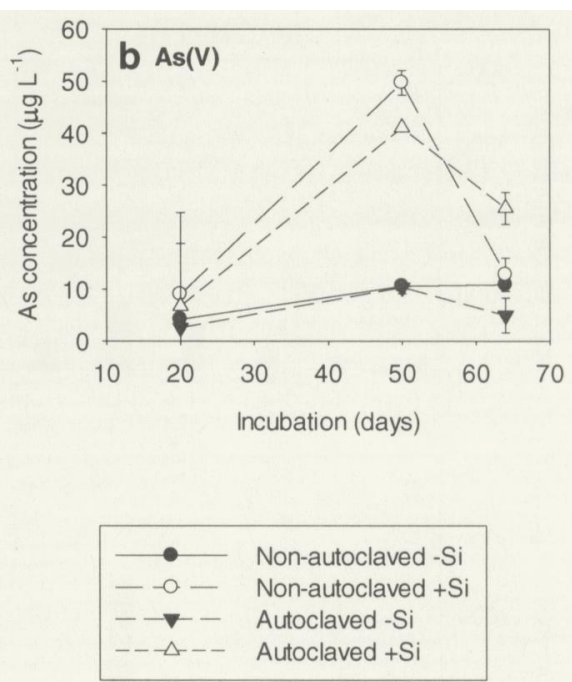

Fig. 2 Effects of Si addition and autoclaving on the dynamics of As species in soil solution in an incubation study without growing rice plants (Data are means $\pm \mathrm{SE}, n=3$ )

comparable physiological stages with panicle emergence as the reference point. As(III) and DMA were the only two As species detected in various plant tissues sampled at panicle emergence and 1 and 2 weeks after flowering (Fig. 4). At 3 weeks after flowering (near grain maturity) when some of the leaves had senesced, small amounts of arsenate were also detected, which was combined with As(III) and shown as inorganic As in Fig. 4g. As(III) was the predominant species in all leaf

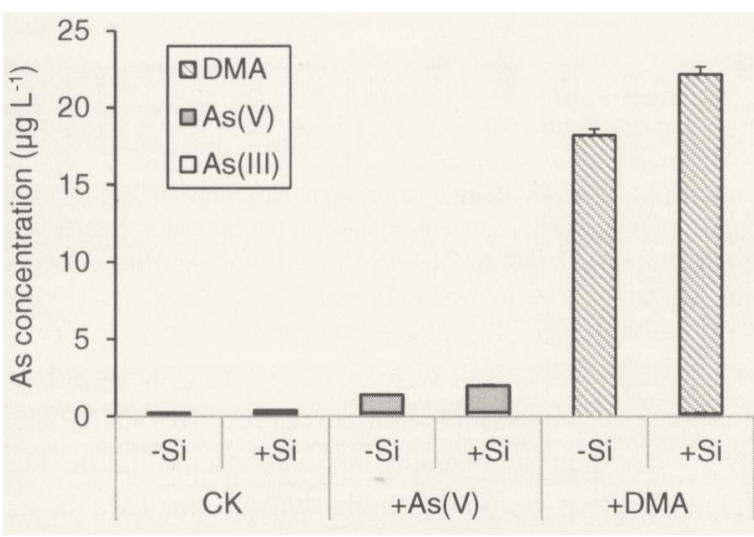

Fig. 3 Effect of Si on the concentrations of arsenic species in soil solution after addition of $1 \mathrm{mg} \mathrm{As} \mathrm{kg}^{-1}$ as $\mathrm{As}(\mathrm{V})$ or DMA (Data are means $\pm \mathrm{SE}, n=4)$. CK, control without the addition of As samples, accounting for $63-100 \%$ of the sum of As species. In contrast, DMA accounted for considerable proportions of the total As in panicles $(61-83 \%)$ and in grain $(50 \%)$. The As(III) concentrations in leaves were markedly larger than those in panicle or gain, whereas the DMA concentrations were broadly comparable between the vegetative and reproductive tissues. The addition of $\mathrm{SiO}_{2}$ gel decreased the As(III) concentration markedly $(P<0.001)$ in different plant tissues from panicle emergence to grain maturity, by $67 \%-95 \%$ in leaves and 65 $92 \%$ in panicle and grain tissues. In contrast, $\mathrm{Si}$ treatment increased DMA concentrations markedly in most samples (Fig. 4). In some samples, DMA was below the detection limit in the -Si treatment but became detectable in the $+\mathrm{Si}$ treatment.

In the experiment with cv. Italica Carolina, only the grain samples at maturity were analysed for As speciation. The results show that $\mathrm{Si}$ addition decreased inorganic As (mainly $\mathrm{As}(\mathrm{III}))$ in grain by $40 \%(P<0.05)$ but increased the DMA concentration by 3.6 fold $(P<0.05$; Fig. 5). Total As concentration in grain was decreased by Si treatment by only $11 \%$. DMA accounted for 9.6 and $39.2 \%$ of the total As in rice grain in the - $\mathrm{Si}$ and + Si treatments, respectively. 

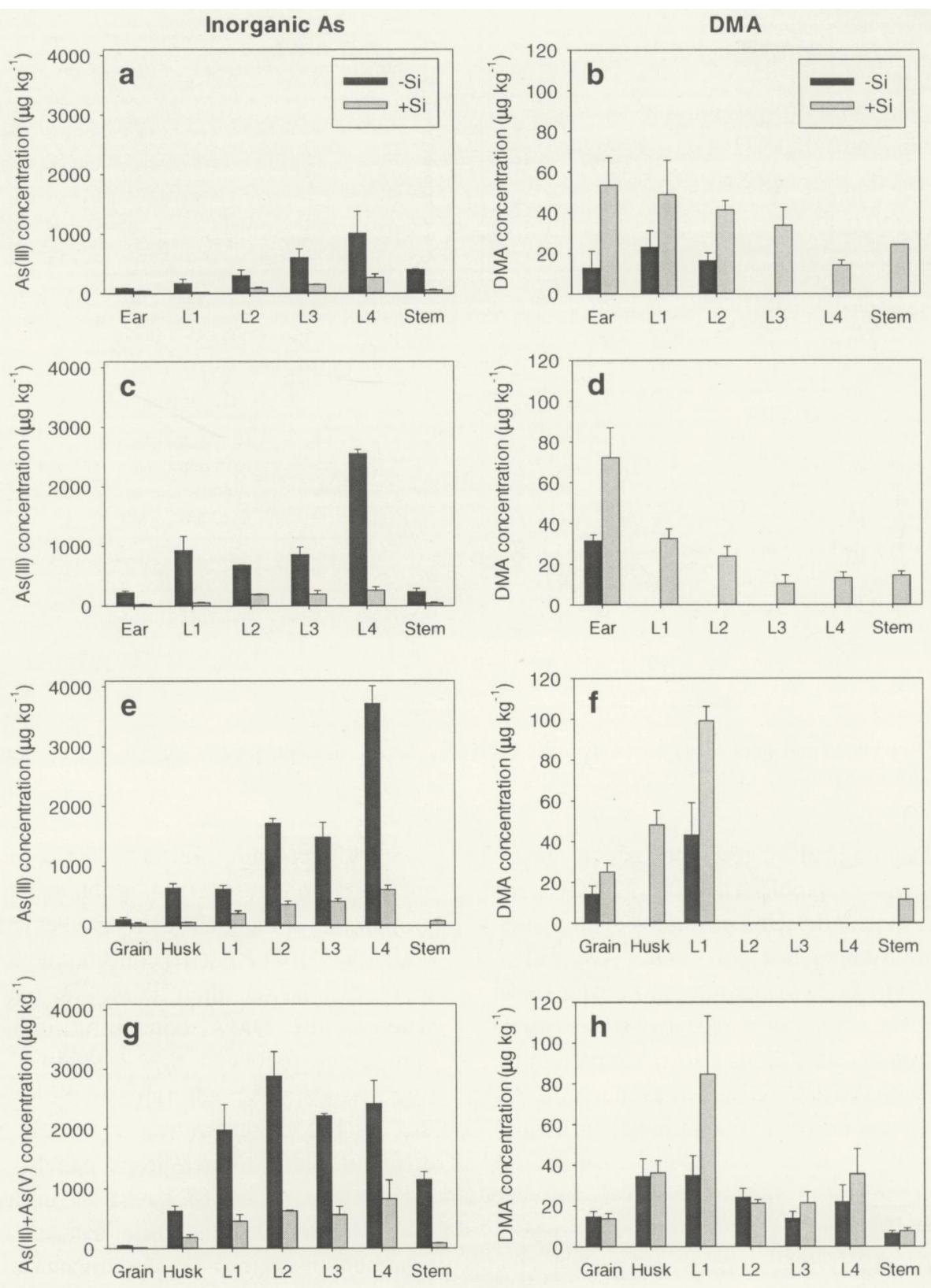

Fig. 4 Effect of $\mathrm{Si}$ on the concentrations of arsenic species in different tissues of rice plants (cv. Oochikara) at the growth stages of panicle emergence (a, b), 1 week after flowering $(\mathbf{c}, \mathbf{d}), 2$ weeks after flowering (e, f) and 3 weeks after flowering $(\mathbf{g}, \mathbf{h})$ (Data are

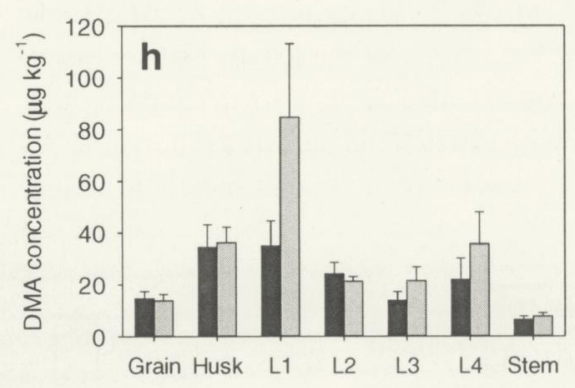

means $\pm \mathrm{SE}, n=4)$. In $(\mathrm{g})$, small concentrations of $\mathrm{As}(\mathrm{V})$ were summed with As(III) concentrations. No bar indicates that As was undectectable. L1-4 denotes the first to the fourth leaf from the top

\section{Discussion}

In the present study, it was found that $\mathrm{Si}$ addition produced opposite effects on the accumulation of inorganic As (mainly arsenite) and methylated As species (mainly DMA) in rice, resulting in a significant decrease of

inorganic As but a substantial increase of DMA. The effect of Si in suppressing arsenite accumulation has been reported before in both hydroponic (Ma et al. 2008) and soil pot experiments (Fleck et al. 2013; $\mathrm{Li}$ et al. 2009b; Seyfferth and Fendorf 2012), and can be explained by the inadvertent uptake of arsenite via the $\mathrm{Si}$ 


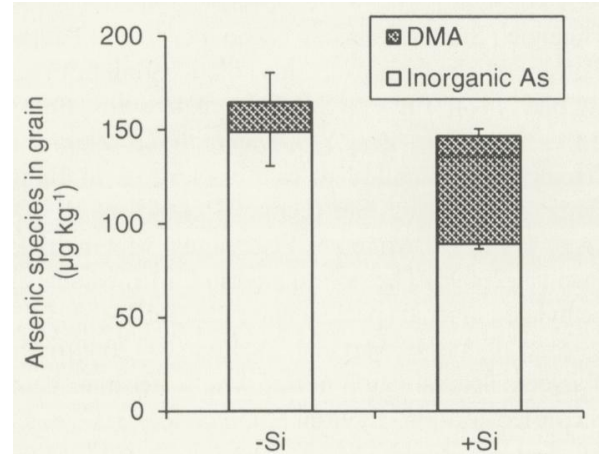

Fig. 5 Effect of $\mathrm{Si}$ on As speciation in rice grain (cv. Italica carolina) at maturity (Data are means $\pm \mathrm{SE}, n=4$ )

transport pathway in rice (Ma et al. 2008). Silicon may suppress arsenite uptake in two ways: a direct competition for membrane transporters, especially Lsi2 (Ma et al. 2008) and a down-regulation of Si transporter genes in rice plants well supplied with $\mathrm{Si}(\mathrm{Ma}$ et al. 2006, 2007). The suppressive effect of $\mathrm{Si}$ is even more remarkable considering that $\mathrm{Si}$ additions tend to increase the concentrations of inorganic As in the soil solution (Li et al. 2009b; Seyfferth and Fendorf 2012) (also Fig. 2), suggesting that the inhibitory effect of Si on arsenite uptake by rice roots far outweighs its mobilizing effect on inorganic As species in the soil solution.

The effect of $\mathrm{Si}$ in increasing DMA concentration in rice grain and husk was first reported by Li et al. (2009b) and further confirmed in the present study for both vegetative and reproductive tissues (Figs. 4 and 5). This effect was puzzling and could not be explained by $\mathrm{Li}$ et al. (2009b). One hypothesis is that Si enhances As methylation in rice plants. However, this can be ruled out because it has recently been shown that rice plants lack the ability to methylate inorganic As and that methylated As species in plants are derived from the soil (Jia et al. 2012; Lomax et al. 2012; Zhao et al. $2013 \mathrm{~b}$ ). The Si/arsenite transporter Lsil is also able to mediate the uptake of undissociated MMA and DMA, although there is no apparent competition between silicic acid and arsenite for this transporter at concentrations normally found in the soil solution ( $\mathrm{Li}$ et al. 2009a). A possible explanation for this lack of competition is that the fluxes of substrates mediated by aquaporin channels (e.g. Lsil) are very fast. Furthermore, mutation of Lsil decreased DMA uptake by rice by approximately $50 \%$ (Li et al. 2009a), suggesting that other uptake pathways may also be involved. In contrast to Lsil, the Si/arsenite efflux transporter Lsi2 is not permeable to methylated
As species (Li et al. 2009a). This difference probably explains why Si suppresses the uptake of arsenite but not of methylated As species in short-term uptake experiments ( $\mathrm{Li}$ et al. 2009a). Thus, the positive effect of Si on DMA accumulation by rice can be attributed to soil physicochemical processes whereby $\mathrm{Si}$ increases the concentration of DMA in the soil solution by displacing adsorbed DMA through ligand exchange or by suppressing the adsorption of DMA (Figs. 1, 2, and 3). It has been shown that silicic acid inhibits the adsorption of arsenite and arsenate on ferrihydrite (Swedlund and Webster 1999) and the adsorption of arsenite on goethite (Luxton et al. 2006), as well as displacing adsorbed arsenite on goethite (Luxton et al. 2008). In the present study, DMA was found to be less adsorbed by the soil used than arsenate (Fig. 3), which is consistent with Xu et al. (1991) who showed that the adsorption of As species on alumina generally decreases with the degree of methylation. Moreover, the effect of $\mathrm{Si}$ on the adsorption of DMA in soil was greater than that of arsenate (Fig. 3), likely due to a weaker adsorption of the former. Taken together, an increased soil solution concentration of DMA in the $+\mathrm{Si}$ treatment and a lack of competition for root uptake would give rise to an increased accumulation of DMA in rice plants. An analogous situation was observed with the addition of phosphate to a flooded soil, which was found to increase the concentration of DMA in rice grain probably through a similar physiochemical mechanism (Wu et al. 2011).

It should be noted that soils vary greatly in the ability to transform inorganic As into methylated As species as a result of differences in the microbial community, soil properties and conditions (Zhao et al. 2013a). This is reflected in the wide variation in the proportion of methylated As species in rice grain (Meharg et al. 2009; Zavala et al. 2008; Zhao et al. 2013b). Although methylated As species usually account for a relatively small proportion of the total soluble As in the soil solution (Zhao et al. 2013a), the much higher mobility of DMA than inorganic As during both the xylem and phloem transport (Carey et al. 2010; Raab et al. 2007; Ye et al. 2010) means that DMA preferentially accumulates and can account for a substantial proportion of the total As in rice grain, even becoming the predominant As species (Zhao et al. 2013b). It is expected that the effect of $\mathrm{Si}$ in enhancing DMA accumulation in rice would be most noticeable in soils having a high capacity to methylate As (e.g. the soil used in the present study 
(Zhao et al. 2013a)). Where the soil has a low capacity to methylate As and consequently inorganic As dominates the As speciation in rice grain, additions of $\mathrm{Si}$ (or P) may not produce a significant positive effect on DMA concentration in rice grain, as was possibly the case in the study reported by Fleck et al. (2013).

The present study has shown that Si supply can have a considerable effect on As speciation in rice grain. Whilst inorganic As is a class one carcinogen, pentavalent DMA is much less toxic to animals and humans (Zhao et al. 2013b). Therefore, Si additions should bring benefits to food safety by decreasing the concentration of inorganic As in rice grain, even if the concentration of DMA is increased. On the contrary, where the Asrelated straight-head disorder in rice is prevalent (Meharg and Zhao 2012), Si additions may exacerbate this problem by increasing the availability of DMA in the soil solution. This study also highlights the need to determine the As speciation in rice grain to better understand the risk of As contamination and the effectiveness of mitigation methods.

Acknowledgments This research was supported by the Natural Science Foundation of China $(41330853,41073074)$, the Innovativc Research Team Development Plan of the Ministry of Education of China (IRT1256) and a Rothamsted International fellowship. Rothamsted Research is supported by the UK Biotechnology and Biological Sciences Research Council. We thank Professor Jian Feng Ma of Okayama University for providing silica gel.

\section{References}

Arao T, Kawasaki A, Baba K, Matsumoto S (2011) Effects of arsenic compound amendment on arsenic speciation in rice grain. Environ Sci Technol 45:1291-1297

Bogdan K, Schenk MK (2008) Arsenic in Rice (Oryza sativa L.) related to dynamics of arsenic and silicic acid in daddy soils. Environ Sci Technol 42:7885-7890

Carey AM, Scheckel KG, Lombi E, Newville M, Choi Y, Norton GJ, Charnock JM, Feldmann J, Price AH, Meharg AA (2010) Grain unloading of arsenic species in rice. Plant Physiol 152: 309-319

European Food Safety Authority (2009) Scientific opinion on arsenic in food. EFSA J 7:1351

Fleck AT, Mattusch J, Schenk MK (2013) Silicon decreases the arsenic level in rice grain by limiting arsenite transport. J Plant Nutr Soil Sci 176:785-794

Hansen HR, Raab A, Price AH, Duan GL, Zhu YG, Norton GJ, Feldmann J, Meharg AA (2011) Identification of tetramethylarsonium in rice grains with elevated arsenic content. J Environ Monitor 13:32-34
Jia Y, Huang H, Sun GX, Zhao FJ, Zhu YG (2012) Pathways and relative contributions to arsenic volatilization from rice plants and paddy soil. Environ Sci Technol 46:8090-8096

Khan MA, Stroud JL, Zhu YG, McGrath SP, Zhao FJ (2010) Arsenic bioavailability to rice is elevated in Bangladeshi paddy soils. Environ Sci Technol 44:8515-8521

Li RY, Ago Y, Liu WJ, Mitani N, Feldmann J, McGrath SP, Ma JF, Zhao FJ (2009a) The rice aquaporin Lsil mediates uptake of methylated arsenic species. Plant Physiol 150:2071-2080

Li RY, Stroud JL, Ma JF, McGrath SP, Zhao FJ (2009b) Mitigation of arsenic accumulation in rice with water management and silicon fertilization. Environ Sci Technol 43:3778-3783

Lomax C, Liu WJ, Wu LY, Xue K, Xiong J, Zhou JZ, McGrath SP, Meharg AA, Miller AJ, Zhao FJ (2012) Methylated arsenic species in plants originate from soil microorganisms. New Phytol 193:665-672

Lombi E, Scheckel KG, Pallon J, Carey AM, Zhu YG, Meharg AA (2009) Speciation and distribution of arsenic and localization of nutrients in rice grains. New Phytol 184:193-201

Luxton TP, Eick MJ, Rimstidt DJ (2008) The role of silicate in the adsorption/desorption of arsenite on goethite. Chem Geol 252:125-135

Luxton TP, Tadanier CJ, Eick MJ (2006) Mobilization of arsenite by competitive interaction with silicic acid. Soil Sci Soc Amer J 70:204-214

Ma JF, Tamai K, Yamaji N, Mitani N, Konishi S, Katsuhara M, Ishiguro M, Murata Y, Yano M (2006) A silicon transporter in rice. Nature 440:688-691

Ma JF, Yamaji N, Mitani N, Tamai K, Konishi S, Fujiwara T, Katsuhara M, Yano M (2007) An efflux transporter of silicon in rice. Nature 448:209-212

Ma JF, Yamaji N, Mitani N, Xu XY, Su YH, McGrath SP, Zhao FJ (2008) Transporters of arsenite in rice and their role in arsenic accumulation in rice grain. Proc Natl Acad Sci U S A 105: 9931-9935

Meharg AA, Williams PN, Adomako E, Lawgali YY, Deacon C, Villada A, Cambell RCJ, Sun G, Zhu YG, Feldmann J, Raab A, Zhao FJ, Islam R, Hossain S, Yanai J (2009) Geographical variation in total and inorganic arsenic content of polished (white) rice. Environ Sci Technol 43:1612-1617

Meharg AA, Zhao FJ (2012) Arsenic \& Rice. Springer, Dordrecht, p 171

Panaullah GM, Alam T, Hossain MB, Loeppert RH, Lauren JG, Meisner CA, Ahmed ZU, Duxbury JM (2009) Arsenic toxicity to rice (Oryza sativa L.) in Bangladesh. Plant Soil 317: 31-39

Raab A, Williams PN, Meharg A, Feldmann J (2007) Uptake and translocation of inorganic and methylated arsenic species by plants. Environ Chem 4:197-203

Seyfferth AL, Fendorf S (2012) Silicate mineral impacts on the uptake and storage of arsenic and plant nutrients in rice (Oryza sativa L.). Environ Sci Technol 46:13176-13183

Stroud JL, Khan MA, Norton GJ, Islam MR, Dasgupta T, Zhu YG, Price AH, Meharg AA, McGrath SP, Zhao FJ (2011) Assessing the labile arsenic pool in contaminated paddy soils by isotopic dilution techniques and simple extractions. Environ Sci Technol 45:4262-4269

Su YH, McGrath SP, Zhao FJ (2010) Rice is more efficient in arsenite uptake and translocation than wheat and barley. Plant Soil 328:27-34 
Swedlund PJ, Webster JG (1999) Adsorption and polymerisation of silicic acid on ferrihydrite, and its effect on arsenic adsorption. Water Res 33:3413-3422

Williams PN, Price AH, Raab A, Hossain SA, Feldmann J, Meharg AA (2005) Variation in arsenic speciation and concentration in paddy rice related to dietary exposure. Environ Sci Technol 39:5531-5540

Williams PN, Raab A, Feldmann J, Meharg AA (2007a) Market basket survey shows elevated levels of As in South Central US processed rice compared to California: Consequences for human dietary exposure. Environ Sci Technol 41:2178-2183

Williams PN, Villada A, Deacon C, Raab A, Figuerola J, Green AJ, Feldmann J, Meharg AA (2007b) Greatly enhanced arsenic shoot assimilation in rice leads to elevated grain levels compared to wheat and barley. Environ Sci Technol 41:6854-6859

Wu ZC, Ren HY, McGrath SP, Wu P, Zhao FJ (2011) Investigating the contribution of the phosphate transport pathway to arsenic accumulation in rice. Plant Physiol 157:498-508

Xu H, Allard B, Grimvall A (1991) Effects of acidification and natural organic materials on the mobility of arsenic in the environment. Water Air Soil Pollut 57-8:269-278

Xu XY, McGrath SP, Meharg A, Zhao FJ (2008) Growing rice aerobically markedly decreases arsenic accumulation. Environ Sci Technol 42:5574-5579
Ye WL, Wood BA, Stroud JL, Andralojc PJ, Raab A, McGrath SP, Feldmann J, Zhao FJ (2010) Arsenic speciation in phloem and xylem exudates of castor bean. Plant Physiol 154:15051513

Zavala YJ, Gerads R, Gürleyük H, Duxbury JM (2008) Arsenic in rice: II. Arsenic speciation in USA grain and implications for human health. Environ Sci Technol 42:3861-3866

Zhao FJ, Harris E, Yan J, Ma JC, Wu LY, Liu WJ, McGrath SP, Zhou JZ, Zhu YG (2013a) Arsenic methylation in soils and its relationship with microbial arsM abundance and diversity, and As speciation in rice. Environ Sci Technol 47:7147-7154

Zhao FJ, McGrath SP, Meharg AA (2010) Arsenic as a food-chain contaminant: mechanisms of plant uptake and metabolism and mitigation strategies. Ann Rev Plant Biol 61:535-559

Zhao FJ, Zhu YG, Meharg AA (2013b) Methylated arsenic species in rice: Geographical variation, origin, and uptake mechanisms. Environ Sci Technol 47:3957-3966

Zheng MZ, Cai C, Hu Y, Sun GX, Williams PN, Cui HJ, Li G, Zhao FJ, Zhu YG (2011) Spatial distribution of arsenic and temporal variation of its concentration in rice. New Phytol 189:200-209

Zhu YG, Sun GX, Lei M, Teng M, Liu YX, Chen NC, Wang LH, Carey AM, Deacon C, Raab A, Meharg AA, Williams PN (2008) High percentage inorganic arsenic content of mining impacted and nonimpacted Chinese rice. Environ Sci Technol 42:5008-5013 